\title{
Socio-demographic and psychological determinants of political (in)tolerance: Hungary at the dawn of the 21 st century ${ }^{1}$
}

\author{
Bojan Todosijević ${ }^{2}$ \\ Institute of Social Sciences, Centre for Political Studies and \\ Public Opinion Research, Belgrade, Serbia \\ Zsolt Enyedi \\ Political Science Department, Central European University, \\ Budapest, Hungary
}

The paper presents a socio-psychological causal model of political intolerance in Hungary, on the basis of a national random sample survey data $(\mathrm{N}=1002)$. The research improves on the existing models in two directions: by constructing a more complete model through inclusion of a wider set of potentially relevant variables, and by using more reliable operationalisation of the examined concepts. The results indicate that political tolerance in Hungary, as defined by the "content free" method, can only weakly be explained by an extensive set of socio-demographic, psychological and political variables. Contrary to the commonly reported results, socio-economic status variables displayed a rather complex and often direct pattern of influence on political tolerance, while psychological variables proved to be relatively weak predictors. In Hungary, psychological factors have a relatively strong role in determining the choice of target groups and socio-demographic variables have a stronger role in determining the degree of intolerance. In general, the findings suggest that intolerance of different groups is not uniformly related to social and psychological explanatory variables.

Key words: political tolerance, quantitative research, Hungary, political attitudes, authoritarianism

\footnotetext{
1 An earlier version of this paper was presented at the $25^{\text {th }}$ Annual Scientific Meeting of the ISPP, Berlin, 16-19 July 2002. 


\section{Introduction}

Political tolerance is one of the basic characteristics of a democratic society. Given the complex heterogeneity of contemporary societies, the citizens of democratic polities are bound to live side by side with people who question their political values or challenge their worldviews. However, in order to protect individual freedoms or/and to reach a pragmatic solution to the dilemmas of social diversity, tolerance appears as a cornerstone-value of the democratic polity.

At the same time, political tolerance is a controversial value. Freedom of political action may be used in order to undermine democratic order. The rhetoric and actions of political organisations can hurt the personal dignity of citizens and threaten the stability of the political regime. As a result, the boundaries of tolerance are permanently contested, even in the most tolerant societies.

Relevance and ambiguity of political tolerance have made it an important subject of social science research. The early studies (Stouffer, 1955; Prothro and Grigg, 1960; McClosky, 1964) demonstrated an unexpectedly strong opposition against granting civil rights to communists, atheists and socialists in the United States. Political intolerance has decreased towards the end of the $20^{\text {th }}$ century. However, its level has remained relatively high, leading some researchers to conclude that "political tolerance is a scarce commodity in the United States” (Gibson, 1989, p. 567).

Evidence from the post-communist countries revealed an unappealing picture - surveys have had a hard time to determine even a few percentages of politically tolerant individuals (e.g. Bahry et al., 1997; Gibson, 1997; Gibson and Duch, 1993; Todosijević, 2011; for a different view see Kaprov, 1999). In light of the apparent intolerance of East Europeans, it is important to examine the sources of the individual-level political intolerance. In the current paper we present an explanatory model of political tolerance on the basis of survey data from Hungary.

Early explanatory studies found that education, generation and age are the most important factors that influence intolerance (Stouffer, 1955). A more elaborate attempt at causal modelling was performed by Sullivan and his co-workers $(1982,1985)$. Their hypothetical causal chain starts with various indicators of socio-demographic background, such as education, age, religion, and occupational status. The next stage is represented by general ideological orientations (e.g., 'conservatism') and psychological characteristics ("psychological security", 1982, p. 213). These two sets of variables were supposed to influence political characteristics of the respondents such as 
political involvement and sophistication. Finally, the perceived threat posed by the target group and the acceptance of democratic norms were the causal variables closest to the explanandum, i.e. the degree of intolerance expressed against the most disliked group.

According to their results, target-group selection is shaped by sociodemographic characteristics since people try to adjust to their social environment in this way. On the other side, the degree of tolerance is "largely a function of externalisation and object appraisal", that is, "individual's level of intolerance will be a direct function of personality and cognitive political factors and not of social factors" (Sullivan et al., 1979,pp. 53-55). Shamir and Sullivan's (1983) analysis of data from theUSA and Israelcorroborated the findings of a differential impact of social and psychological variables. ${ }^{3}$ More recent comparative research, however, found little support for their hypothesis about different roots of the degree and direction of political intolerance (e.g. Todosijević, 2008, 2011).

In the present analysis we examine whether the causal model proposed by Sullivan and his co-workers is able to account for individual differences in the degree of political intolerance in Hungary. We particularly focus on their hypothesis on different effects of socio-economic and psychological variables, which has recently been challenged in comparative research (Todosijević, 2011). We are improving on the existing models in two directions. First, we present a more complete model, by including a wider set of variables that could be expected to play a role in the development of individual political intolerance. Most importantly, we include a set of outgroup-related attitudes in the position of immediate antecedents of political intolerance. Commonly analysed factors, such as the economic background or personality, have to be 'transferred' into particular orientation towards outgroups in order to have an influence on intolerance. For example, economic frustration can make one adopt a radically unconventional political outlook which could involve tolerance, and not intolerance, of the commonly disliked groups.

Second, we construct a more reliable operationalisation for some of the examined concepts, compared to the ones often found in the literature. It particularly concerns the socio-economic variables. Commonly, they are operationalised via only several variables, while we included a much wider set of relevant variables, and reduced them to a smaller set of more general factors, in order to achieve wider and more reliable measures.

First part of the analysis examines the determinants of the choice of a target group, a group that is least liked and towards which the intolerance is

3 See also Sullivan et al. (1985) for the comparison of the USA, Israel and New Zealand. 
directed. The second part examines a causal model aimed at explaining the degree of political intolerance.

Although the data were collected in November 2000, the scientific relevance of the analysis is not time-bound for two main reasons. One is that the main theoretical problem, i.e. the determinants of individual differences in political tolerance, is of continued significance, and the relevant knowledge is only enriched by every piece of additional evidence from different places and periods. Second, the results describing a particular time and place are important as a benchmark for any subsequent research. In order to trace changes over time, or space, evidence from different periods and regions is indispensable. However, the results cannot be taken as representing the current state of affairs in Hungary, as both dependent and independent variables can be expected to vary with social and political changes. Thus, the results and their theoretical implications are relevant beyond the specific time and place, perhaps especially relevant for countries with similar political history, such as Hungary and Serbia.

\section{Method}

This research is based on a survey of a national random sample of Hungarian citizens ( $\mathrm{N}=1002$, non-response rate approximately $30 \%)$. The survey took place in Hungary, November $14-28^{\text {th }}, 2000$. The 120 locations where our respondents were interviewed were stratified by region and type of settlement. The age of the respondents was between 18 and 79. They were chosen according to a combination of a random route method and a quota which required the sample to be representative in terms of sex, education and age. Data collection procedure conformed to the research ethics standards.

\section{Variables}

Table 1 gives an overview of the included variables. Socio-economic status(SES) is operationalised through three factor scores, on the basis of a number of specific indicators such as income, education, possessions of material goods, and subjective perception of one's economic status. This is a more reasonable approach than to simply focus on educational level, since it is not an isolated socio-economic variable, but co-varies with a number of other phenomena. The first SES factor (SES_01) divides those who reach the basic economic standards (and have high family income) from those who do not, the second (SES_02) contrasts people with high subjective status, high income, and high education with those who have low subjective status, 
low income and low education, but the factor is dominated by the subjective status, and the other two variables only marginally contribute to it. The third SES factor (SES_03) divides those who possess quality goods from those who do not. For more details, see Appendix.

The political-ideological set of variables is extensive. First, it includes measures of ideological self-description: identification with conservatism, liberalism and socialism labels and the left-right self-identification scale. The pro-democratic orientation variable corresponds to Sullivan et al's support for democratic norms - one of the most important predictors of political tolerance. Egalitarian orientation (e.g. support for equality, minority rights) is also expected to positively correlate with political tolerance. Security values (e.g. order, discipline) are expected to negatively correlate with tolerance, especially as far as political outgroups are perceived as a threat to social order and provoke insecurity feelings (perceived threat commonly correlates with intolerance; see Sullivan et al., 1982). Finally, since most of the studies found that tolerance is related to political sophistication or political involvement, we include the variable of political interest which is constructed as the principal component of three variables: reading about politics in dailies and monthlies, and self-expressed political interest.

Psychological variables are represented by authoritarianism and social dominance orientation. Authoritarianism is operationalised by the $1^{\text {st }}$ principal component of a 10-item scale which was built from the items from the F-scale and RWA scale. Sample item: "The most important virtues a child has to learn are obedience and respect for authority." Reliability coefficient for the summarised scale is Alpha=.77.4 Social Dominance Orientation scale (Pratto et al., 1994) contains 10 items (Alpha=.66), designed to measure individual's preference for hierarchical social relations. ${ }^{5}$ These two constructs are expected to be related to political tolerance both on the basis of theoretical reasons and on the basis of previous research (e.g. Altemeyer, 1988; Sidanius et al, 1994).

4 The entire scale is published in Todosijević\&Enyedi(2008), one difference being that the current scale contains 10 items instead of 9. The additional item is "It is nothing wrong to have nudist beaches in our country", a slightly reformulated item No. 8 from Altemeyer's 1997 RWA scale (Altemeyer, 1998, p. 86).

5 Although the reliability coefficient is modest in magnitude, and lower than usually obtained in Anglophone countries, it is well within the range of coefficients obtained crossnationally (see Pratto et al., 2013, p. 590, Table 2; de Regt, 2012). Part of the explanation is also that the scale is "composed of two subdimensions, reflecting the preference for group-based dominance hierarchies (SDO-D) and opposition to egalitarian intergroup relations (SDO-E)." (Ho et al., 2012, p. 587). 
Table 1. Variables used for causal modelling of political tolerance

\begin{tabular}{|c|c|c|}
\hline Theoretical variable & Code-label used in analysis & Empirical measures \\
\hline \multirow[t]{4}{*}{$\begin{array}{l}\text { Socio-demographic } \\
\text { background }\end{array}$} & $\begin{array}{l}\text { Budapest, local capital, city, } \\
\text { village }\end{array}$ & $\begin{array}{l}\text { Place of residence-degree of } \\
\text { urbanization }\end{array}$ \\
\hline & $\begin{array}{l}\text { Catholic, Greek Catholic, } \\
\text { Lutheran, Calvinist, not } \\
\text { member }\end{array}$ & Religious denomination \\
\hline & Church attendance & $\begin{array}{l}\text { Church attendance (from " } 1 \text { Does not } \\
\text { go" to " } 6 \text { Many times a week") }\end{array}$ \\
\hline & Religiosity & $\begin{array}{l}\text { Religiosity (from " } 1 . \text { I am religious" } \\
\text { to "4. I am not religious") }\end{array}$ \\
\hline \multirow[t]{3}{*}{ Socio-economic status } & SES_01 & $\begin{array}{l}\text { F1: Possession of basic economic } \\
\text { standard }\end{array}$ \\
\hline & SES_02 & F2: Subjective status \\
\hline & SES_03 & $\begin{array}{l}\text { F3: Possession of higher socio- } \\
\text { economic standard }\end{array}$ \\
\hline \multirow[t]{8}{*}{$\begin{array}{l}\text { Political-Ideological } \\
\text { variables }\end{array}$} & Left-Right scale & Left-Right ideological self-placement \\
\hline & Conservative identification & $\begin{array}{l}\text { Conservative ideological self- } \\
\text { identification }\end{array}$ \\
\hline & Liberal identification & Liberal ideological self-identification \\
\hline & Socialist identification & Socialist ideological self-identification \\
\hline & Pro-democracy & Pro-democracy orientation \\
\hline & Egalitarianism & Egalitarian value orientation \\
\hline & Security orientation & Security value orientation \\
\hline & Political interest & Political interest \\
\hline \multirow[t]{2}{*}{ Psychological variables } & Authoritarianism & Authoritarianism scale \\
\hline & SDO & Social Dominance Orientation scale \\
\hline \multirow[t]{4}{*}{$\begin{array}{l}\text { Outgroups related } \\
\text { attitudes }\end{array}$} & GATO & $\begin{array}{l}\text { GATO scale-General attitude towards } \\
\text { outgroups }\end{array}$ \\
\hline & Dislike & $\begin{array}{l}\text { Degree of antipathy towards the } \\
\text { target group }\end{array}$ \\
\hline & Outgroups sympathy F1 & Sympathy towards political outgroups \\
\hline & Outgroups sympathy F2 & - two factors \\
\hline $\begin{array}{l}\text { Political intolerance } \\
\text { variables }\end{array}$ & Political intolerance & $\begin{array}{l}\text { Intolerance of civil liberties scale } \\
\text { (principal component) - the 'least- } \\
\text { liked' measure }\end{array}$ \\
\hline
\end{tabular}

Note: Details on the variable definition and measurement can be found in Appendix.

Outgroup-related attitudes begin with the general attitude towards outgroups, measured by theGATO scale, which consists of 'feeling thermometer' items concerning 13 non-political outgroups, from Roma and the homeless to Germans and Jews. Previous research found that this variable correlates with authoritarianism and specific ethnic prejudices (Todosijević \& Enyedi, 2004).

Degree of sympathy for political outgroups is included as a separate variable. The seven political outgroups are those included in the list from 
which respondents selected their least-liked group. Since political intolerance is dispersed or "pluralistic" in Hungary, these variables were factor-analysed. The results showed that sympathy towards political outgroups has two major dimensions (Outgroups sympathy F1 and F2, see Appendix). The positive side of the first factor is defined by the sympathy for the pro-choice activists, while the negative side is defined by the rejection of the anti-abortionists and xenophobes. The second factor united the positive evaluation of the other four groups, but with the strongest influence of the sympathy for the supporters of Communism and religious sects.

Finally, "Dislike" is a variable constructed by including the degree of sympathy for the group each respondent chose as the most disliked, i.e. the target group. This variable represents distilled intensity of the negative emotion directed to the personally chosen political outgroup. Thus, the four outgroup-related variables represent the general attitude towards outgroups (GATO), the attitude towards examined political outgroups (Outgroups sympathy F1 and F2), and the intensity of the antipathy against the target group (Dislike).

Political tolerance index, i.e. the dependent variable in our model, was constructed following the Sullivan et al.s 'least-liked' or 'content free' approach. The variable is represented by the first principal component of four items asking whether the members of the least-liked group should be allowed to teach in state schools, organise public demonstrations, place their propaganda books in public libraries, and be nominated for public office. Alpha reliability coefficient is .87 .

\section{Results}

The choice of a target group

Respondents were asked to select the least-liked group from an offered list (the so called "least-liked" method of measuring intolerance). The list referred to theorganisations whose members: 1 . Support the present day Yugoslav regime, ${ }^{6}$ 2. Want to send away all foreigners from the country, 3 . Want to forbid abortion completely, 4 . Represent the interests of the homosexuals, 5 .

6 At the time of the survey there was a controversy concerning various activist groups that were voicing support to the "Miloševićs regime", by organising public protests during the NATO aggression against Yugoslavia. The official policy of the Hungarian government was supportive of the aggression. The opposed groups were ideologically heterogeneous, but publicly mostly associated with the former Communist party of Hungary. Another complication arises from the fact that Milošević had lost the election just before the survey fieldwork, when it was too late to change the question wording. Hence, the ambiguity of the question: it asks about "the present day Yugoslav regime", meaning Miloševićs government, but at the time of the survey the regime had already changed. However, according to the polling agency, the intention of the question was clear to the respondents. 
Are the adherents of Communism, 6. Represent the religious sects, 7. Want to make abortion completely free. The responses are shown in Figure 1.

The relative majority of respondents (30\%) chose the religious sects, $22 \%$ picked the homosexuals, and $15 \%$ those who would forbid abortion. On the other extreme, only $4 \%$ chose those organisations that wanted to make abortion completely free.The respondents were then asked "Is there any group that is even more antipathetic?" Some $89 \%$ answered no, which indicates that the questionnaire covered the potential political targets well. ${ }^{7}$

Question text. Among the [mentionad] organizations which is the most antipativetic? Those who

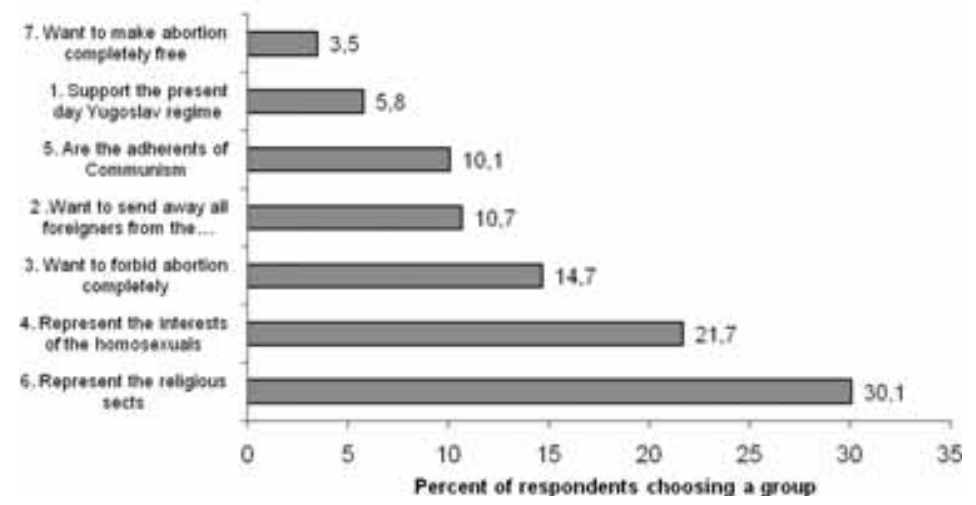

Figure 1. The least-liked political organisation - distribution of answers

In order to examine whether target-group selection is rooted in social background variables, we performed a series of variance analyses with a set of standard socio-demographic variables. The results, presented inTable 2, show that most of the included variables are significantly related with the target group selection. In way of an example, older respondents more often disliked groups that represent homosexuals and pro-choice activists. The better educated and economically well-off often chose communists and xenophobes as their least-liked groups, while less educated and poorer respondents more often chose groups promoting interests of homosexuals. Religiosity and church attendance were related in a predictable way: less religious and less frequent church-goers more often selected xenophobes and anti-abortionists, while the religious disliked pro-choice activists. Hence, the findings corroborate the first Sullivan et al's hypothesis, though the relationships are not particularly strong.

7 Respondents are generally reluctant to name additional groups by themselves. Gibson and Duch (1993), for example, had only two additionally mentioned groups that exceeded occurrence of $1 \%$. 
Table 2. Mean scores on the background variables and the most disliked group

\begin{tabular}{lcccccc}
\hline \multicolumn{1}{c}{$\begin{array}{c}\text { The most antipathetic group. } \\
\text { Those who.. }\end{array}$} & Sex $^{\mathrm{a}}$ & Age & Education & Income & Religiosity $^{\mathrm{b}}$ & $\begin{array}{c}\text { Church } \\
\text { attend. }^{\mathrm{c}}\end{array}$ \\
$\begin{array}{l}\text { 1. Support the present day } \\
\text { Yugoslav regime }\end{array}$ & $\mathrm{F}+$ & 47.3 & 2.93 & 39629 & 2.78 & 4.66 \\
$\begin{array}{l}\text { 2.Want to send away all } \\
\text { foreigners from the country }\end{array}$ & $\mathrm{M}+$ & 40.4 & 3.50 & 43058 & 2.94 & 5.02 \\
$\begin{array}{l}\text { 3. Want to forbid abortion } \\
\text { completely }\end{array}$ & $\mathrm{F}+$ & 41.7 & 3.21 & 39397 & 2.78 & 4.92 \\
$\begin{array}{l}\text { 4. Represent interests of the } \\
\text { homosexuals }\end{array}$ & $\mathrm{M}+$ & 48.4 & 2.93 & 35537 & 2.35 & 4.43 \\
$\begin{array}{l}\text { 5. Are the adherents of } \\
\text { communism }\end{array}$ & $\mathrm{M}+$ & 44.4 & 3.49 & 43946 & 2.50 & 4.48 \\
$\begin{array}{l}\text { 6. Represent the religious sects } \\
\text { 7. Want to make abortion }\end{array}$ & $\mathrm{F}+$ & 44.4 & 3.30 & 41340 & 2.78 & 4.74 \\
completely free & $\mathrm{M}+$ & 47.0 & 3.06 & 40959 & 2.31 & 4.24 \\
& & & & & & \\
F & 2.61 & 3.51 & 6.18 & 2.84 & 3.93 & 3.78 \\
Significance (p) & .01 & .001 & .001 & .01 & .001 & .001 \\
\hline
\end{tabular}

${ }^{a}$ This column shows which gender chose a respective group more often than according to marginal distribution.

${ }^{\mathrm{b}}$ Higher score indicates lower religiosity.

${ }^{c}$ Higher score indicates less frequent church attendance.

According to Sullivan et al's hypothesis, psychological and ideological variables should be related only with the intensity of intolerance, not so much with its direction. The results in Table 3 show that this hypothesis is not substantiated in Hungary. Most of the analysed variables are significantly related with group-selection, and the relationships appear to be stronger than in the case of socio-demographic variables. Authoritarianism and the general attitude towards outgroups (GATO) seem to be especially powerful predictors of the target-group selection. Pro-choice and pro-homosexuals activists are groups most likely to be selected by highly authoritarian individuals. Low authoritarianism is related with the dislike of xenophobes and anti-abortionists, and somewhat less with the dislike of religious sects. Expectedly, the dislike of xenophobes is also strongly related with the positive GATO scores. Somewhat surprisingly, however, the social dominance orientation proved unrelated with the target-group selection. This seems to be a consequence of the fact that this scale functions differently in the postcommunist context (e.g. De Regt, Smits \& Mortelmans, 2010).

Concerning the ideological self-identification, the right-wing identifiers dislikedcommunists and pro-choice activists, while left-wingers disproportionally disliked the religious sects and anti-abortionists. Socialist identification is 
related in a similar way as left-wing identification, but conservative and liberal identifications proved to be unrelated to group selection.

Finally, the pro-democratic orientation makes one more likely to chose communists and xenophobes as the most disliked groups, while those scoring low on this scale were more negatively disposed towards homosexuals and religious sects (and the former Yugoslav regime). Politically interested individuals also disliked xenophobes and Communists relatively more, while those less interested were negative towards the activists representing the prochoice option and homosexuals.

Table 3. Psychological and ideological variables and choice of the most disliked group

\begin{tabular}{|c|c|c|c|c|c|c|c|c|c|}
\hline $\begin{array}{l}\text { The most antipathetic } \\
\text { group }\end{array}$ & 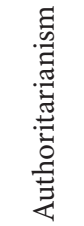 & คิ & 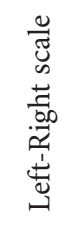 & 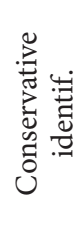 & 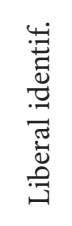 & 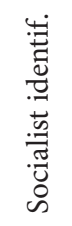 & 怘 & 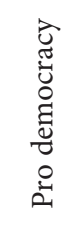 & $\begin{array}{l}\overrightarrow{0} \\
\overrightarrow{0} \\
\overrightarrow{0} \\
. \\
\overrightarrow{0} \\
\dot{0}\end{array}$ \\
\hline $\begin{array}{l}\text { 1. Support the present } \\
\text { day Yugoslav regime }\end{array}$ & .15 & 23.98 & 4.96 & 2.98 & 3.11 & 3.13 & -.15 & -.16 & -.09 \\
\hline $\begin{array}{l}\text { 2. Want to send away } \\
\text { all foreigners from the } \\
\text { country }\end{array}$ & -.45 & 22.46 & 4.91 & 3.04 & 3.45 & 3.33 & .64 & .25 & .33 \\
\hline $\begin{array}{l}\text { 3. Want to forbid } \\
\text { abortion completely }\end{array}$ & -.17 & 24.42 & 4.54 & 2.93 & 3.22 & 3.37 & .04 & -.04 & -.06 \\
\hline $\begin{array}{l}\text { 4. Represent the interests } \\
\text { of the homosexuals }\end{array}$ & .46 & 24.31 & 4.78 & 3.15 & 3.09 & 3.31 & -.36 & -.10 & -.15 \\
\hline $\begin{array}{l}\text { 5. Are the adherents of } \\
\text { communism }\end{array}$ & -.07 & 23.20 & 5.53 & 3.10 & 3.19 & 2.63 & -.06 & .38 & .22 \\
\hline $\begin{array}{l}\text { 6. Represent the } \\
\text { religious sects }\end{array}$ & -.12 & 23.49 & 4.48 & 2.93 & 3.22 & 3.33 & -.01 & -.13 & .03 \\
\hline $\begin{array}{l}\text { 7. Want to make } \\
\text { abortion completely free }\end{array}$ & .34 & 23.26 & 5.26 & 3.00 & 3.03 & 3.09 & .15 & .01 & -.22 \\
\hline $\mathrm{F}$ & 12.37 & 1.21 & 4.87 & 1.67 & 2.55 & 8.07 & 11.64 & 4.17 & 3.36 \\
\hline Significance $(p)$ & .001 & n.s. & .001 & n.s. & n.s. & .001 & .001 & .001 & .01 \\
\hline
\end{tabular}

It is clear that both SES and psychological-ideological variables determine the choice of a target group. Authoritarianism and generalised attitude towards outgroups are the strongest factors in general, while education is the strongest factor within the group of demographic variables.

Hence, the choice of a target group is firmly rooted both in the sociodemographic background and at least as strongly in one's ideological orientation and personality structure. There is a clear trend that, for example, xenophobes are especially disliked by non-authoritarian, politically interested, 
pro-democracy oriented individuals, with a general positive attitude towards outgroups, and among younger, better educated, well-off, secular respondents. Homosexuals and pro-abortionists are disliked generally by individuals with the opposite characteristics.

\section{The degree of intolerance: statistical modelling}

In order to examine the determinants of the degree of political intolerance we constructed a causal model, which at the general level resembles the standard model of Sullivan et al. (1982). The hypothetical causal chain starts from the basic socio-demographic indicators, and in each further step contains variables conceptually closer to the explanandum. The general order of variables is presented in Table 4(the causal chain starts from the left side).

Table 4. Order of variables in the hypothetical explanatory model of political tolerance

\begin{tabular}{|c|c|c|c|c|}
\hline $\begin{array}{l}\text { Background } \\
\text { variables }\end{array}$ & $\begin{array}{l}\text { Psychological } \\
\text { variables }\end{array}$ & $\begin{array}{l}\text { Political-ideological } \\
\text { variables }\end{array}$ & $\begin{array}{c}\text { Outgroup-related } \\
\text { attitudes }\end{array}$ & $\begin{array}{l}\text { Political } \\
\text { tolerance }\end{array}$ \\
\hline $\begin{array}{l}\text { Age, gender, } \\
\text { type of the place } \\
\text { of residence }\end{array}$ & Authoritarianism & $\begin{array}{c}\text { Ideological } \\
\text { identification (left- } \\
\text { right, conservative, } \\
\text { liberal, socialist) }\end{array}$ & $\begin{array}{l}\text { General attitude } \\
\text { towards outgroups }\end{array}$ & \\
\hline $\begin{array}{l}\text { Religious } \\
\text { denomination, } \\
\text { religiosity, } \\
\text { church } \\
\text { attendance }\end{array}$ & $\begin{array}{l}\text { Social } \\
\text { Dominance } \\
\text { Orientation }\end{array}$ & $\begin{array}{l}\text { Pro-democratic } \\
\text { orientation }\end{array}$ & $\begin{array}{c}\text { General sympathy } \\
\text { for political } \\
\text { outgroups }\end{array}$ & $\begin{array}{l}\text { The 'least } \\
\text { liked' } \\
\text { measure } \\
\text { of political } \\
\text { intolerance }\end{array}$ \\
\hline \multirow[t]{3}{*}{$\begin{array}{l}\text { Socio-economic } \\
\text { status }\end{array}$} & & Egalitarian values & $\begin{array}{l}\text { Sympathy } \\
\text { for the target } \\
\text { group (the most } \\
\text { dislikedpolitical } \\
\text { outgroup) }\end{array}$ & \\
\hline & & Security values & & \\
\hline & & Political interest & & \\
\hline
\end{tabular}

We adopted the simplest method of causal modelling, relying on a series of multiple regression analyses. Variables within each of the sets (e.g. background variables, or psychological variables) are treated as variables on equal footing, i.e. not as explanatory to each other. Variables in the blocks left of a particular variable are treated as explanatory variables. Thus, for example, the least liked' index of intolerance is regressed on all variables within the blocks on its left side. When a variable is regressed onto its predictor variables, we do not control for the variables within the same block as the given dependent variable (for example, when regressing authoritarianism, we do not control for SDO). 
The results of the regressionanalyses are presented in several steps, starting from Table 5and ending with Table 7. As the first column of coefficients in Table 5shows, although the relationship is statistically significant $(\mathrm{p}<.001)$, the explained variance of the political tolerance index is low (adjusted $\mathrm{R}^{2}=.12$ ). Compare the obtained $12 \%$ with more than $50 \%$ obtained in Israel and USA by Shamir and Sullivan (1983).

There are few explanatory variables with direct influence on this political tolerance index. Some of them, contrary to the Sullivan model, are sociodemographic factors. Political tolerance is lower among the older cohorts and among those who lack basic material conditions (the first SES factor). In addition, the residents of Budapest appear to be more tolerant. Psychological variables (Authoritarianism and SDO) do not exhibit a direct influence. Out of nine political-ideological variables, only one directly influences political tolerance - the egalitarian value orientation, and the effect is weak and negative. The outgroup-related attitudes have a stronger influence. The generalised positive attitude towards outgroups (GATO) enhances political tolerance, as well as one of the factors of sympathy towards political outgroups (sympathy towards communists, sects and homosexuals).

Thus, many of the commonly obtained predictors of tolerance failed to reach statistical significance (e.g. authoritarianism, ideological identification). It is important to note that some of the social variables exhibit a significant direct effect, while personality traits proved weak in this regard.

When we turn to the variables immediately antecedent to the intolerance index, we first observe that the model fails to explain the intensity of antipathy against the selected group ('dislike'; the fifth column in Table 5). Modest three percents of the variance are explained by younger age, lower authoritarianism, and stronger emphasis on security values (remember that the variable "dislike" is coded in reverse order). Of the three coefficients, two are in the unexpected direction: older age is usually associated with intolerance, and authoritarianism should predispose individuals to stronger negative attitudes. 
Table 5. Multivariate model of political tolerance, with the 'least-liked' measure as a dependent variable (first part)

\begin{tabular}{|c|c|c|c|c|c|}
\hline Variable & Beta & Beta & Beta & Beta & Beta \\
\hline Sex & -.02 & .05 & .01 & -.01 & -.02 \\
\hline Age & $-.13^{\star \star}$ & -.05 & -.05 & -.05 & $.11^{\star}$ \\
\hline Catholic denomination & .03 & .14 & .09 & -.04 & -.01 \\
\hline Greek-catholic denomination & .03 & .00 & -.04 & -.04 & -.05 \\
\hline Calvinist denomination & .05 & .02 & .06 & -.10 & .02 \\
\hline Lutheran denomination & .02 & $.11^{*}$ & -.05 & -.07 & -.06 \\
\hline Budapest & $.19^{* * *}$ & $.12^{\star *}$ & .05 & .07 & -.05 \\
\hline County capital & .07 & .07 & -.03 & $-.09^{*}$ & .03 \\
\hline City & .07 & .05 & -.04 & -.01 & -.01 \\
\hline SES_01 & $-.14^{\star *}$ & .05 & .04 & .02 & .06 \\
\hline SES_02 (reversed) & -.08 & .00 & .05 & -.06 & .02 \\
\hline SES_03 & .02 & -.04 & .02 & $.10^{*}$ & .03 \\
\hline Church attendance & .02 & $-.15^{\star *}$ & -.08 & -.01 & -.01 \\
\hline Religiosity (reversed) & .07 & .04 & -.07 & -.05 & -.10 \\
\hline Authoritarianism & -.09 & $-.21^{\star \star \star}$ & -.03 & $-.17^{\star \star \star}$ & $.15^{\star * *}$ \\
\hline SDO & .08 & -.00 & .06 & $-.20^{* * *}$ & .05 \\
\hline Conservative identification & -.00 & .01 & -.03 & .02 & -.06 \\
\hline Liberal identification & -.07 & .07 & -.04 & .03 & .00 \\
\hline Socialist identification & .02 & .02 & $.13^{\star *}$ & -.03 & .01 \\
\hline Left-right scale & -.05 & -.03 & -.06 & -.07 & .07 \\
\hline Pro-democracy & .05 & .05 & .03 & $.14^{\star * \star}$ & -.03 \\
\hline Egalitarianism & $-.12^{*}$ & $.21^{* * *}$ & .09 & $.15^{\star * *}$ & -.00 \\
\hline Security orientation & .04 & -.01 & -.00 & -.03 & $-.16^{* * *}$ \\
\hline Political interest & .08 & .03 & $-.10^{\star}$ & .07 & .03 \\
\hline Outgroups sympathy F1 & .03 & $\begin{array}{c}\text { Adj. } \\
\mathrm{R}^{2}=.19\end{array}$ & & & \\
\hline Outgroups sympathy F2 & $.14^{* *}$ & & $\begin{array}{c}\text { Adj. } \\
\mathrm{R}^{2}=.04\end{array}$ & & \\
\hline GATO & $.15^{\star *}$ & & & $\begin{array}{c}\text { Adj. } \\
\mathrm{R}^{2}=.21\end{array}$ & \\
\hline Dislike of target group (reversed) & .08 & & & & $\begin{array}{c}\text { Adj. } \\
\mathrm{R}^{2}=.03\end{array}$ \\
\hline Political tolerance index & $\begin{array}{c}\text { Adj. } \\
\mathrm{R}^{2}=.12\end{array}$ & & & & \\
\hline
\end{tabular}

Note: For all regression equations $\mathrm{F}$ test is significant $(\mathrm{p}<.01)$.

${ }^{*} \mathrm{p}<.05,{ }^{* *} \mathrm{p}<.01,{ }^{* * *} \mathrm{p}<.001$.

The model is more successful in explaining variance in the GATO scale ( $21 \%$ of the variance). The possession of quality goods, egalitarian and prodemocratic value orientations all significantly increase the sympathy towards the non-political outgroups. Authoritarianism and SDO have the opposite 
effects. Thus, this measure of the outgroup-related attitudes is closer to the usual findings concerning political intolerance. Social variables do not have direct influence, while personality and political-ideological variables are strong direct predictors.

Although the first dimension of the sympathy for political outgroups (Outgroups sympathy F1-pro-choice vs. anti-abortionists and xenophobes) was not related to the tolerance index, the variable itself can be relatively well explained by the model $\left(\mathrm{R}^{2}=.19\right)$. Rare church attendance, membership in the Lutheran church, residence in Budapest, egalitarian values and low authoritarianism all contribute to the support of pro-choice groups and against the pro-life and xenophobic groups.

The second dimension of sympathy for political outgroups (Outgroups sympathy F2-communists, sects, etc.) is considerably less related to the analysed predictor variables. Only $4 \%$ of variance in the sympathy for these groups could be explained by socialist ideological identification, and lower political involvement.

Going further towards the beginning of the hypothesized causal chain, that is, towards the political variables (Table 6), we find that about $7 \%$ of variance in the socialist identification can be explained by older age, the possession of basic economic standard, but also the lack of more luxury goods, less frequent church attendance, and lower social dominance orientation. Pro-democratic value orientation is negatively related to Catholic and Calvinist denomination, higher subjective economic standard (SES_02 variable is coded in reverse), religiosity, and most strongly with authoritarianism. Egalitarian value orientation is, expectedly, strongly negatively related to the SDO scale, but also to low authoritarianism and female gender. The security values have rather similar predictors, with the exception that authoritarianism increases this orientation. Political involvement is predicted by male gender and older age, higher economic standard, low authoritarianism and low SDO. Thus, most of the obtained relationships are expected, though often of low magnitude. 
Table 6. Multivariate model of political tolerance, with the least-liked measure as a dependent variable (continuation)

\begin{tabular}{|c|c|c|c|c|c|}
\hline Variable & Beta & Beta & Beta & Beta & Beta \\
\hline Sex & .04 & -.03 & $.14^{\star \star \star}$ & -.03 & $-.13^{\star *}$ \\
\hline Age & $.19^{\star * *}$ & .04 & .07 & $.10^{*}$ & $.18^{\star * *}$ \\
\hline Catholic denomination & .10 & $-.19^{\star}$ & -.08 & .03 & .00 \\
\hline Greek-catholic denom. & .01 & -.03 & -.02 & -.01 & -.02 \\
\hline Calvinist denomination & .10 & $-.14^{\star}$ & -.03 & -.02 & .06 \\
\hline Lutheran denomination & -.02 & -.02 & .06 & .05 & -.07 \\
\hline Budapest & .04 & .03 & $-.10^{\star}$ & -.05 & .05 \\
\hline County capital & -.07 & .06 & .00 & .00 & .05 \\
\hline City & -.08 & .06 & -.07 & -.08 & -.04 \\
\hline SES_01 & $.11^{\star}$ & .09 & .06 & $.11^{\star}$ & $.15^{\star *}$ \\
\hline SES_02 (reversed) & .04 & $-.13^{\star *}$ & .01 & .01 & $-.22^{\star * *}$ \\
\hline SES_03 & $-.10^{*}$ & .00 & .04 & -.02 & .06 \\
\hline Church attendance & $-.13^{\star *}$ & -.02 & .01 & -.02 & .02 \\
\hline Religiosity (reversed) & .08 & $-.13^{\star *}$ & $-.10^{\star}$ & $-.16^{\star *}$ & -.01 \\
\hline Authoritarianism & -.05 & $-.17^{\star * *}$ & $-.13^{\star *}$ & $.15^{\star * *}$ & $-.11^{\star \star}$ \\
\hline $\mathrm{SDO}$ & $-.09^{*}$ & -.06 & $-.31^{\star * *}$ & $-.22^{* * *}$ & $-.19^{\star * *}$ \\
\hline Socialist identification & $\begin{array}{c}\text { Adj. } \\
\mathrm{R}^{2}=.07\end{array}$ & & & & \\
\hline Pro-democracy & & Adj. $R^{2}=.08$ & & & \\
\hline Egalitarianism & & & $\begin{array}{c}\text { Adj. } \\
\mathrm{R}^{2}=.17\end{array}$ & & \\
\hline Security orientation & & & & $\begin{array}{c}\text { Adj. } \\
\mathrm{R}^{2}=.11\end{array}$ & \\
\hline Political interest & & & & & $\begin{array}{c}\text { Adj. } \\
\mathrm{R}^{2}=.16\end{array}$ \\
\hline
\end{tabular}

Note: For all regression equations $\mathrm{F}$ test is significant $(\mathrm{p}<.01)$. The results for variables that have no direct or indirect effect onto political tolerance or outgroup-related attitudes (i.e. liberal and conservative identifications, left-right identification) are not presented.

${ }^{*} \mathrm{p}<.05,{ }^{* *} \mathrm{p}<.01,{ }^{* * *} \mathrm{p}<.001$.

Finally, personality features can also be predicted on the basis of their predictor variables, but again relatively modestly (Table 7). Authoritarianism is lower among younger respondents, and among dwellers in local capitals and cities. The lack of basic economic standard increases authoritarianism, which is also the case for the lack of luxury goods, though to a lesser extent. The SDO is considerably less rooted in the socio-demographic variable: males are more socially dominant in Hungary just as everywhere else where the scale has been used. Greek Catholics and Lutherans also appear to be more dominance-oriented. Higher economic standard, logically, also contributes to higher SDO scores. 
Table 7. Multivariate model of political tolerance, with the least-liked measure as a dependent variable (final part)

\begin{tabular}{lcc}
\hline \multicolumn{1}{c}{ Variable } & Beta & Beta \\
\hline Sex & -.03 & $-.16^{* * *}$ \\
Age & $.09^{*}$ & -.04 \\
Catholic denomination & .05 & .14 \\
Greek-catholic denomination & .05 & $.18^{* *}$ \\
Calvinist denomination & .11 & .13 \\
Lutheran denomination & .02 & $.11^{*}$ \\
Budapest & -.06 & .02 \\
County capital & $-.17^{* * *}$ & -.04 \\
City & $-.13^{* *}$ & .03 \\
SES_01 & $-.11^{* *}$ & .00 \\
SES_02 (reversed) & .04 & -.03 \\
SES_03 & $-.08^{*}$ & $.10^{* *}$ \\
Church attendance & .08 & .01 \\
Religiosity (reversed) & $-.10^{*}$ & .07 \\
\hline Authoritarianism & Adj. $\mathrm{R}^{2}=.14$ & \\
SDO & & Adj. $\mathrm{R}^{2}=.05$ \\
\hline
\end{tabular}

Note: For both regression equations $\mathrm{F}$ test is significant $(\mathrm{p}<.01)$.

${ }^{\star} \mathrm{p}<.05,{ }^{* *} \mathrm{p}<.01,{ }^{* * *} \mathrm{p}<.001$.

\section{Discussion of the causal modelling results}

Due to the large number of variables entered into the analysis it would be difficult to draw a legible graphical presentation of the findings. Instead of drawing a graph, we will summarize the most important aspects of the presented explanatory model of political tolerance. Since the coefficients and the explained variances were rather small, one must remember that the paths of influence outlined below account only for a modest portion of the dependent variables' variance.

According to the obtained results, political tolerance is most closely related to the general attitude towards outgroups (GATO) and the attitude towards certain political outgroups (Factor 2 -communists, sects, homosexuals and the former Yugoslav regime). Egalitarian values exhibit negative direct influence on it, though more modestly. Background variables such as age, residence in Budapest, and basic economic standard also directly influence tolerance.

The GATO mediates the influence of egalitarian and pro-democratic values, authoritarianism, and social dominance orientation. The other main independent variable, sympathy for political outgroups (Factor 2), is rooted in socialist ideological identification. Age exhibits positive influence on political tolerance via this second route, too, since it strengthens the socialist identification, which further leads to a more positive attitude towards some 
of the political outgroups, which, in turn, finally results in higher tolerance scores. This is the only path through which church attendance also exhibits some indirect influence (by decreasing the socialist identification). A part of this path goes via political involvement, which is weakly related to positive outgroup evaluation (Factor 2).

Authoritarianism is the most important mediator of the influence of the possession of basic socio-economic goods and of residence. The lack of the basic economic standard increases authoritarianism, which then increases a negative general attitude towards outgroups (GATO), probably through some frustration-aggression mechanism. Authoritarianism indirectly influences intolerance through political values (egalitarian and pro-democratic) and through inhibiting political involvement as well.

The social dominance orientation mediates the influence of sex, denomination, and higher economic standard. The SDO transfers these influences on political tolerance, primarily through GATO scores, i.e. by reducing the positive general evaluation of outgroups. However, the SDO also increases tolerance by making people less egalitarian and more socialist.

Socio-economic background variables showed a surprisingly strong and diverse role in shaping political tolerance. Gender has a complex indirect role. Women tend to be more egalitarian (lower SDO and higher egalitarian values). Thus, through egalitarian values women tend to be more intolerant, but through their lower SDO scores they are also less negative about outgroups and therefore more tolerant.

Age also exhibits a contradicting influence. It decreases tolerance directly, but enhances it via socialist identification. Urbanisation has a positive influence on political tolerance directly and indirectly via authoritarianism as well.

The role of basic economic standards is also complex. Surprisingly, the direct effect of possessing basic material conditions on tolerance is negative. However, strong indirect influence of this aspect of social status reduces intolerance by reducing the level of authoritarianism. ${ }^{8}$

The dimension of subjective aspects of economic status indirectly contributes to political tolerance by increasing GATO scores. Higher economic standard, however, has contradictory effects. It increases tolerance via GATO scores, but it also decreases GATO scores by increasing SDO scores. Thus, the role of socio-economic status indicators proves to be extremely complex.

The variables related to religion exhibit modest indirect influences. Religious denomination matters in case of the SDO scores. Church attendance matters for the socialist identification (through this path church attendance decreases tolerance), but also for the (negative) attitude towards pro-abortion

8 Zero-order correlation between tolerance and "basic standard" is insignificant. However, subjective economic status and higher economic status are positively related with tolerance at the zero-order level. 
political activists. Religiosity modestly contributes to political tolerance by enhancing pro-democratic attitude and thereby GATO scores.

This rather extensive analysis can be concluded by emphasising that many of the present findings are in accordance with the findings of other researchers in other countries (Sullivan et al., 1982, 1985; Todosijević, 2011; Crawford \& Pilanski, 2014).For example, authoritarianism reduces tolerance, even if in an indirect way. However, many of the obtained results depart from the general findings of the scholars in the field, or the relationships prove to be more complex than often believed, as long as intolerance is measured by the "least liked" method. In Hungary, for example, social variables still play an important direct role in determining the degree of political intolerance. Egalitarian values also exhibited unexpected effects, reducing the level of tolerance.

Our findings also point to the complex role of the background variables. Several of them exhibited opposing effects. Thus, we argue that if background variables are measured in a more complex manner, i.e. not only as income and several grades of educational attainment, the conventional theories about the role of these variables have to be reconsidered.

\section{General conclusions}

The results showed that the presented model explains about $12 \%$ of variance in political intolerance. This finding, and some of those concerning the determinants of political intolerance, resembles theresults obtained in other countries (Sullivan et al., 1982, 1985; Todosijević, 2011; Crawford \& Pilanski, 2014). However, we obtained a clear-cut difference in both the level of explained variance and in the role of some of the independent variables. Most importantly, it proved that psychological variables play only a minor role in explaining the degree of intolerance, similar as in recent comparative research (Todosijević, 2011).

In order to understand this result, we must re-consider the Sullivantype operationalisation of tolerance. While at the normative level political tolerance must be defined with reference to groups one dislikes and opposes politically, we have enough evidence to argue that intolerance of different groups is not uniformly related to social and psychological explanatory variables (cf. Gibson, 1992; Todosijević, 2011).Our results have shown that it does matter which group is chosen as the most disliked. The intolerance of different groups has different social and psychological roots. Political values, ideological identification, and outgroup-related attitudes are important determinants of the target group selection. 'Hard' social variables are also influential in this regard, but their influence seems to be more indirect. Most importantly, as shown in the first part of the analysis, personality seems to be at least as strong a determinant of the direction as it is of the intensity of 
intolerance. Hence, we have the strong effect of psychological factors already in-built within the 'least-liked' index of intolerance. Since, for example, authoritarianism positively correlates with the dislike of pro-choice activists, and negatively with the dislike of xenophobes, it is logical that it does not correlate with an index that combines them both. The link that establishes this connection in Hungary is the fact that whatever the selected target group is, it is rather uniformly strongly not-tolerated. The finding of widespread intolerance, defined in this manner, is in agreement with other reports on post-communist countries (e.g. Bahry et al., 1997; Gibson, 1997; Gibson and Duch, 1993, Todosijević, 2008).

This pattern of relationships seems to be applicable to the countries where intolerance is dispersed and where the society is not clearly segmented along social or ethnic lines (or at least when reference to such groups is not part of the operationalisation of intolerance). In homogeneous societies the choice of an enemy appears to be determined not so much by socialisation but by psychological features, ideological and value orientations. The difference in the political-cultural context leads to the inverse of the American and Israeli pattern: in Hungary, psychological factors have a relatively strong role in determining the choice of target groups, while socio-demographic variables have a relatively strong role in determining the degree of intolerance. Just as intolerance is pluralistic, the mechanisms behind intolerance seem to be pluralistic, too. Since the "least-liked" type of intolerance index summarises all these different mechanisms, it is not so surprising that such internally heterogeneous variable is hard to explain. More generally, our principal objection to the Sullivan et al.'s index of intolerance is that there is little reason to expect that the psychological foundation of the intolerance of xenophobes and the intolerance of pro-choice and pro-homosexuals activists is the same. This measure is irreproachable for the purpose of the normative assessment of the level of abstract political intolerance, but explanation of individual differences has to take into account the character of target groups. This observation does not invalidate the Sullivan-type operationalisation, but calls for a parallel employment of a number of measures instead.

\section{References}

Altemeyer, B. (1988). Enemies of Freedom: Understanding Right-Wing Authoritarianism. San Francisco, CA: Jossey-Bass Publishers.

Altemeyer, B. (1998). The other "Authoritarian Personality". Advances in experimental social psychology, 30, 47-92.

Bahry, D., Boaz, C. \& Gordon, S. B. (1997). Tolerance, transition, and support for civil liberties in Russia. Comparative Political Studies, 30, 484-511.

Crawford, J. T., \& Pilanski, J. M. (2014). The Differential Effects of Right-Wing Authoritarianism and Social Dominance Orientation on Political Intolerance. Political Psychology, 35, 557-576. 
De Regt, S., Smits, T., \& Mortelmans, D. (2010). On cross-national variation in the correlation between authoritarianism and social dominance orientation. PCSPolitics, Culture and Socialization, 1, 311-322.

de Regt, S. (2012). Religiosity as a moderator of the relationship between authoritarianism and social dominance orientation: A cross-cultural comparison. International Journal for the Psychology of Religion, 22, 31-41.

Enyedi, Zs. and Todosijević, B. (2001). Political Tolerance in Hungary. Working Paper \#13, Budapest: CEU, Political Science Department.

Gibson, J. L. (1989). The structure of attitudinal tolerance in the United States. British Journal of Political Science, 19, 562-570.

Gibson, J. L. (1992). Alternative measures of political tolerance: Must tolerance be 'lest -liked? American Journal of Political Science, 36, 560-577.

Gibson, J. L. (1997). Mass opposition to the Soviet putsch on August 1991: Collective action, rational choice, and democratic values in the former Soviet Union. American Political Science Review, 91, 671-684.

Gibson, James L., \& Duch, Raymond M. (1993). Political intolerance in the U.S.S.R.: The distribution and etiology of mass opinion. Comparative Political Studies, 26, 286-329.

Ho, A. K., Sidanius, J., Pratto, F., Levin, S., Thomsen, L., Kteily, N., \& SheehySkeffington, J. (2012). Social Dominance Orientation Revisiting the Structure and Function of a Variable Predicting Social and Political Attitudes. Personality and Social Psychology Bulletin, 38, 583-606.

Kaprov, Vyacheslav (1999). Political Tolerance in Poland and the United States. Social Forces, 77, 1525- 1550.

McClosky, Herbert. (1964). Consensus and ideology in American politics. American Political Science Review, 58, 361-382.

Pratto, F., Çidam, A., Stewart, A. L., Zeineddine, F. B., Aranda, M., Aiello, A., ... \& Henkel, K. E. (2013). Social dominance in context and in individuals: Contextual moderation of robust effects of social dominance orientation in 15 languages and 20 countries. Social Psychological and Personality Science, 4, 587-599.

Prothro, James W., \& Grigg, Charles W. (1960). Fundamental principles of democracy: Bases of agreement and disagreement. Journal of Politics, 22, 276-294.

Shamir, Michael, \& Sullivan, John. (1983). The political context of tolerance: The United States and Israel. American Political Science Review, 77, 911-928.

Sidanius, J., Stallworth, L. M. \& Malle, B. F. (1994). Social dominance orientation: A personality variable predicting social and political attitudes. Journal of Personality and Social Psychology, 67,741-763.

Stouffer, Samuel C. (1955). Communism conformity, and civil liberties. New York: Doubleday.

Sullivan, John L., Piereson, James, \& Marcus, George E. (1979). An Alternative Conceptualisation of Political Tolerance: Illusory Increases, 1950's-1970's. American Political Science Review, 73, 781-794.

Sullivan, J. L., Piereson, J., and Marcus, G. E. (1982). Political Tolerance and American Democracy. Chicago: University of Chicago Press. 
Sullivan, J. L., Shamir, M., Walsh, P.\& Roberts, N. S. (1985). Political Tolerance in Context.Boulder, CO: Westview.

Todosijević, B. (2008). Politička tolerancija u Srbiji i Evropi: Društveni i psihološki koreni. Psihologija, 41, 455-487.

Todosijević, B. (2011). Pluralistic political intolerance: A comparison of Eastern and Western Europe. Politics, Culture and Socialization, 2,221-235.

Todosijević, B. \& Enyedi, Zs. (2004). Kulturális elvárás vagy/és személyiség? Romaellenes elõítéletek Magyarországon. Educatio, 13, 567-582.

Todosijević, B. \& Enyedi, Zs. (2008). Authoritarianism without Dominant Ideology: Political Manifestations of Authoritarian Attitudes in Hungary. Political Psychology, 29, 767-787.

\section{Sociodemografske i psihološke odrednice političke (ne)tolerancije: Mađarska na pragu 21. veka}

\section{Bojan Todosijević}

Institut društvenih nauka, Centar za politikološka istraživanja i javno mnenje, Beograd, Srbija

\section{Zsolt Enyedi}

Odeljenje za političke nauke, Centralnoevropski univerzitet, Budimpešta, Mađarska

U radu se predstavlja sociopsihološki kauzalni model političke tolerancije u Mađarskoj na osnovu podataka dobijenih u nacionalnom istraživanju sprovedenom na slučajnom uzorku $(\mathrm{N}=1002)$. Postojeći modeli dopunjuju se ovim istraživanjem u dva pravca: konstruisanjem potpunijeg modela kroz uključivanje šireg skupa potencijalno relevantnih varijabli i korišćenjem pouzdanije operacionalizacije koncepata koji su predmet istraživanja. Rezultati pokazuju da se politička tolerancija u Mađarskoj, definisana pomoću metodene zavisne od sadržaja, može samo delimično objasniti širokim skupom sociodemografskih, psiholoških i političkih varijabli. Za razliku od rezultata dobijenih u dosadašnjim studijama, pokazalo se da varijable socioekonomskog statusa imaju prilično složen i često direktan uticaj na političku toleranciju, dok su psihološke varijable relativno slabi prediktori. Psihološki faktori imaju veliki uticaj na izbor ciljne grupe, dok sociodemografski faktori igraju veću ulogu u određivanju stepena netolerancije. Nalazi istraživanja generalno pokazuju da netolerancija različitih grupa nije uniformno povezana sa socijalnim i psihološkim eksplanatornim varijablama.

Ključne reči: politička tolerancija, kvantitativno istraživanje, Mađarska, politički stavovi, autoritarnost. 


\section{APPENDIX: \\ Variables used in the analysis}

\section{Socio-economic status (SES)}

SES is a variable constructed via factor analysis.

Initial variables included:

- Income self-assessment (D15). Three-point variable: 1- below average, 2-average, 3 -above average.

- Poor-Rich self-assessment (D16). 10-point variable, from 1-poor, to 10-rich.

- Class self-assessment (D17). 6-point variable, from "1. lower class" to "6. upper class".

- Perceived relative financial status (D18). Financial status of the household as compared to the majority of the country: from " 1 . much worse" to "5. much better off"

- Change of the financial status (D19). Question: How did the financial status of your family change in the last 5 years? From "1. became much worse" to " 5 . became much better".

- Material possessions variables. 13 yes-no type of items, referring to the possession of various material goods.

- Respondent's education (D3) (6 categories)

\section{SES Factor analysis (SES_01, SES_02, SES_03)}

Factor analysis resulted in three factors (according to Scree test), explaining $40.2 \%$ of the total variance (eigenvalues are: $26.2,7.4$, and 6.6 ).

Table 1. Socio-Economic Status: Pattern matrix of the Oblimin rotated factors

\begin{tabular}{lccc}
\hline & Factor 1 & Factor & Factor \\
\hline Possession of: Washing machine & .68 & & \\
Possession of: Microwave oven & .65 & & \\
Possession of: VCR & .65 & & \\
Family income & .56 & & \\
Possession of: TV with teletext & .55 & & \\
Possession of: HI-FI & .49 & & \\
Possession of: Telephone & .43 & & .31 \\
Possession of: Mobile telephone & .42 & & \\
D16 Poor-Rich self assessment & & -.83 & \\
D19 Change of the financial status & & -.78 &
\end{tabular}


D18 Perceived relative financial status $\quad-.76$

D17 Class self-assessment $\quad-.59$

Income $\quad-.50$

Education $\quad-.33$

Possession of: Internet $\quad .62$

Possession of: PC $\quad .58$

Possession of: Video camera $\quad .55$

Possession of: Summer cottage $\quad .52$

Possession of: Dish washer $\quad .49$

Possession of: New car $\quad .39$

Note: Loadings above .30 shown.

Interpretation:

- Factor 1: Basic economic standard (code-label: SES_01)

- Factor 2: Subjective assessment of the SES (code-label: SES_02)

- Factor 3: Higher socio-economic standard (code-label: SES_03)

\section{Political-Ideological variables}

Left-Right ideological self-placement scale

10-point scale, from "1. Left" to "10. Right".

Ideological self-identification

Question: Q3. How strongly you do you identify with the following political labels: Conservative, Liberal, Socialist.

Answer options: from "1. Strongly antipathetic" to "5. Completely identify".

\section{Pro-democracy orientation}

First principal component (38.6\% of the variance) on the basis of 4 items representing attitude towards democracy (5-point Likert format; higher score -higher agreement).

Q30. Parliamentary democracy is not able to resolve crisis situations.

Q35. Since 1990 people can influence the fate of the country better.

Q32. In spite of its weaknesses, parliamentary system functions well in Hungary.

Q31. Multiparty-system is an impediment in front of the national unity.

\section{Egalitarian value orientation}

First principal component (accounting for $51.0 \%$ of the variance) on the basis of 3 items representing egalitarian value orientation. Questions asked about the support for policies aimed at improving: Equality of women, Minority rights, Equality (5-point Likert format; higher score -higher agreement). 


\section{Security values}

First principal component (accounting for $62.5 \%$ of the variance), based on 3 items (5-point Likert format, higher score -stronger approval) asking about the approval of values: Discipline, Order, Responsibility.

\section{Out-group related attitudes}

GATO scale

General Attitude Towards Outgroups: First principal component of a 13item scale consisting of the 'feeling thermometer' items referring to outgroups from skinheads and Roma to Germans and Jews.

Higher score indicates a more positive general attitude towards outgroups. Alpha reliability coefficient is Alpha $=.88$.

\section{Degree of sympathy for the most disliked group (Dislike)}

Dislike scale represents the sympathy of the group chosen as the most disliked. Before asking the respondents about the most disliked group, they were asked to express their sympathy for seven political outgroups on the 5-point Likert-type scale (1 -antipathetic, 5 -sympathetic).

\section{Sympathy towards political outgroups (GRTOL_F1 and GRTOL_F2)}

Likert-type items measuring the degree of sympathy towards the examined political outgroups were factor-analysed. According to the Scree test, two factors were extracted, accounting for $42.4 \%$ of the scale variance. The Oblimin rotated factors are: 1) Pro-choice vs. pro-life and xenophobia factor, and 2) general sympathy for political outgroups factor.

Table 2. Two Oblimin factors of the attitude towards political outgroups (pattern matrix)

\begin{tabular}{lcc}
\hline \multicolumn{1}{c}{ Sympathy for the political outgroup } & Factor 1 & Factor 2 \\
\hline 1. Support the present day Yugoslav regime & & .43 \\
2. Want to send away all foreigners from the country & -.46 & \\
3. Want to forbid abortion completely & -.84 & \\
4. Represent the interests of the homosexuals & .37 & .57 \\
5. Are the adherents of communism & & .63 \\
6. Represent the religious sects & -.30 & .64 \\
7. Want to make abortion completely free & .66 & \\
\hline
\end{tabular}

